\title{
KAJIAN TENTANG PERJANJIAN EKSTRADISI INDONESIA-MALAYSIA DALAM MEMBERANTAS KEJAHATAN DAN PELAKSANAANNYA DI INDONESIA
}

\author{
Rika Erawaty
}

Fakultas Hukum Universitas Mulawarman

\begin{abstract}
Today ,Advances in technology and transportation are not only have a positive impact for the development of a country, but also a negative impact on their lives. With progress on the one hand it can provide for someone who wants to break away lawsuits. With the transportation advancement he could go to a single country to another country, mainly to neighboring countries which were located near to their home countries, which purpose is to break away lawsuits. For example Malaysia-Indonesia geographic and cultural factors might criminals to escape. Based on the background that the perceived need for a treatment between Indonesia and Malaysia regarding the transfer of criminals who fled. The agreement set forth in the form of Extradition Treatment, an agreement regarding the transfer of a person who has committed a criminal act to another country which is have right for judgment. The agreement stipulated in law No.9 of 1974, and this agreement has prompted Indonesia to ratify and develop national legislation on extradition, namely Law No. 1 of 1979.
\end{abstract}

Key Words: Ekstradisi (Extradition), Pelaku kejahatan (actor)

\section{A. PENDAhULUAN}

Perkembangan dan kemajuan dibidang ilmu pengetahuan serta teknologi dewasa ini mempunyai pengaruh yang sangat besar terhadap perkembangan kejahatan pada umumnya dan kejahatan-kejahatan bertaraf internasional pada khususnya. Dengan adanya kemajuan komunikasi dan transportasi antar Negara, maka akan lebih memudahkan seseorang yang telah melakukan tindak pidana disuatu Negara dalam waktu yang sangat singkat dan dengan cara yang begitu mudah akan dapat melarikan diri ke negara lain untuk melepaskan diri dari jangkauan yurisdiksi Negara dimana mereka melakukan tindak pidana kejahatan tersebut. Setiap orang yang telah melakukan tindak pidana kejahatan harus mampu mempertanggung jawabkan perbuatannya atau kejahatan yang telah dilakukannya. Akan tetapi, tidak setiap orang akan rela mempertanggung jawabkan perbuatannya itu. Dia akan berusaha menghindarkan diri dari tuntutan dan ancaman hukuman yang dijatuhkan terhadapnya. Salah satu cara yang cukup efektif untuk menyelamatkan diri adalah dengan melarikan diri kedalam wilayah negara lain.

Bilamana hal yang demikian dibiarkan begitu saja, maka perkembangan kejahatan akan senantiasa terus meningkat dan para penjahat-penjahat besar berkeliaran dari negara satu ke negara lainnya tanpa dikenakan hukuman. Hal demikian jelas akan mengancam keamanan masyarakat internasional, serta keamanan dan kedamaian yang dicita-citakan tidak akan pernah terwujud. 
Salah satu sarana yang dilakukan untuk menanggulangi masalah tersebut adalah melalui suatu lembaga yang disebut "EXTRADITION" atau penyerahan penjahat antar negara". Penyerahan penjahat menunjukkan suatu proses dimana suatu Negara menyerahkan atas permintaan negara lainnya seseorang yang dituduh atau dihukum karena melakukan tindak pidana yang melanggar undang-undang negara pemohon. Akan tetapi, penyerahan tersebut tidak semudah yang dibayangkan, penjahat tersebut tidak dapat begitu saja dipulangkan ke nagara asalnya. Perlu adanya suatu kerjasama antara negara-negara, baik itu bersifat bilateral maupun internasional.

Ekstradisi merupakan bantuan hukum yang bersifat internasional. Dengan adanya bantuan ini, maka negara asing yang merasa berhak untuk menuntut seseorang yang berada disuatu negara, dapat melakukan haknya. Untuk dapat menyerahkan seorang penjahat ke negara lain harus ada persetujuan antara negara yang bersangkutan mengenai penyerahan tersebut serta harus adanya undang-undang atau aturan yang mengatur hal ini. ${ }^{2}$

Dalam hal ini aparat dari negara yang dirugikan tidak dapat begitu saja memasuki wilayah territorial negara lain untuk menangkap pelaku kejahatan tersebut. Hal ini karena di dalam hukum internasional berlaku prinsip penghormatan kedaulatan masing-masing negara sehingga untuk memasuki negara lain pun harus ada persetujuan terlebih dahulu dari negara yang akan dimasuki. ${ }^{3}$ Oleh karena itu dirasakan perlunya ada suatu perjanjian dan perundang-undangan khusus mengatur mengenai pemulangan pelaku kejahatan.

Namun demikian walaupun ada perundang-undangan yang mengatur mengenai penyerahan penjahat ini,akan tetapi masih terdapat hambatan-hambatan didalam pelaksanaannnya. Ada tiga faktor utama yang cendrung menghambat kerjasama internasional dalam usaha pemberantasan kejahatan ini, yaitu: ${ }^{4}$

1. Perbedaan struktur kepolisian yang sering mempersulit negara lain untuk mengetahui departemen manakah yang bertanggung jawab untuk meberikan informasi mengenai suatu kasus.

2. Adanya perbedaan bahasa yang dipergunakan tiap-tiap negara sehingga merupakan rintangan dari segi komunikasi.

3. Sistem-sistem yang beraneka ragam.

Permasalahannya, banyak perjanjian baik bilateral maupun multilateral dan undang-undang nasional yang merumuskan bahwasanya suatu negara dapat menolak untuk mengekstradisikan seorang penjahat karena penuntutan maupun pemidanaan terhadapnya telah kadaluawarsa (lapse of time), ${ }^{5}$ sehingga apabila telah mengalami kadaluwarsa maka mereka dapat kembali ke Negara tempat melakukan kejahatan dengan aman tanpa mendapat tuntutan hukum. Hal ini juga diakui oleh bangsa Indonesia sebagaimana yang termuat dalam Pasal 12 Undang-Undang Nomor 1 Tahun 1979 Tentang Ekstradisi yang berbunyi :

1 Abdurrahman, SH, Aneka Masalah Hukum Dalam Perkembangan Di Indonesia, Alumni Bandung, 1979, hal 114

2 Prof Sudarto, SH, Hukum Pidana I, Yayasan Sudarto, Semarang, 1990, hal 36

${ }^{3}$ Dr. FX. Adji Samekto, SH., M.H, Negara Dalam Dimensi Hukum Internasional, Citra Aditya Bakti, Bandung, 2009, hal 88

${ }^{4}$ Sardjono, Kerjasama Internasional Dibidang Kepolisian, National Central Bureau Indonesia-Interpol, Jakarta, 1996, hal 20

${ }^{5}$ M. Budiarto, SH, Masalah Ekstradisidan Jaminan Perlindungan Atas Hak-hak asasi Manusia, Ghalia, Jakarta, 1980, hal 17 
"Permintaan ekstradisi ditolak jika menurut hukum Negara Republik Indonesia hak untuk menuntut atau hak untuk melaksanakan pidana telah kadaluwarsa".

Adapula suatu negara tidak mau menyerahkan pelaku kejahatan kepada negara yang tidak memiliki yurisdiksi terhadap pelaku kejahatan tersebut dengan alasan kedua negara belum mengadakan perjanjian ekstradisi. Sebagimana perjanjian pada umumnya, ada yang bilateral dan ada yang multilateral, demikian pula halnya dengan perjanjian ekstradisi itu sendiri ada yang bilateral dan ada yang multilateral. Perjanjian ekstradisi bilateral biasanya diadakan antara negara-negara dimana frekuensi orang atau pelaku kejahatan yang melarikan diri ke dalam wilayah masing-masing pihak cukup banyak jumlahnya atau antara negara-negara yang secara geografis berdekatan letaknya. Contoh perjanjian ekstradisi bilateral ini adalah:

1. Perjanjian ekstradisi antara Pemerintah Indonesia dengan Pemerintah Malaysia tahun 1974 (telah diratifikasi oleh pemerintah Indonesia dengan Undang-Undang Nomor 9 Tahun 1974) yang merupakan awal lahirnya perjanjian ekstradisi antara Indonesia dengan Negara-negara lain, dan lahirnya Undang-undang No.1 Tahun 1979 Tentang Ekstradisi.

Secara geografis, Malaysia merupakan negara tetangga yang terdekat dengan Indonesia. Sehingga memungkinkan penjahat untuk melarikan diri dengan mudahnya. Hal ini dikarenakan antara Indonesia dengan Malaysia banyak mempunyai persamaan baik dari segi bahasa, agama, maupun adat istiadatnya. Untuk mengatasi masalah tersebut, maka dirasakan perlu adanya pengaturan yang lebih tegas dalam menangani masalah kejahatan dan pemulangan penjahat tersebut ke negara asalnya. Semua ini dimaksudkan agar terciptanya keamanan, ketertiban, dan persahabatan antara pemerintah Indonesia dengan pemerintah Malaysia. Oleh sebab itu, maka Republik Indonesi telah mengadakan perjanjian ekstradisi dengan negara Malaysia pada tanggal 7 Juni 1974.

1. Perjanjian Ekstradisi antara Indonesia dengan Filipina 1976 (telah diratifikasi oleh pemerintah Indonesia dengan Undang-Undang Nomor 10 Tahun 1976)

2. Perjanjian ekstradisi antara Indonesia dan Thailand 1978 (telah diratifikasi oleh pemerintah Indonseia dengan Undang-Undang Nomor 2 Tahun 1978).

Contoh Perjanjian Ekstradisi multilateral:

1. Perjanjian Ekstradisi Liga Arab tanggal 14 September 1952

2. Konvensi Ekstradisi Negara-Negara Eropa tanggal 13 Desember 1957

3. Konvensi Ekstradisi Negara-Negara Benelux (Belgia,Nederland, dan Luksemburg) tanggal 27 Juni 1962.

Negara-negara yang sudah terikat dalam perjanjian ekstradisi multilateral, tetap masih bisa membuat perjanjian ekstradisi bilateral dengan sesama negara yang juga terikat dalam perjanjian ekstradisi multilateral atau sebaliknya dua negara yang sebelumnya telah terikat pada perjanjian ekstradisi bilateral juga tetap masih bisa ikut serta dalam perjanjian ektradisi multilateral yang diadakan kemudian. 


\section{B. RUMUSAN MASALAH}

Berdasarkan uraian tersebut diatas, yang menjadi permasalahan adalah sebagai berikut:

1. Bagaimanakah pelaksanaan perjanjian ekstradisi antara pemerintah Indonesia dengan pemerintah Malaysia?

2. Apakah manfaat perjanjian ekstradisi itu sendiri bagi pemerintah Indonesia dan pemerinth Malaysia?

\section{PEMBAHASAN}

\section{EKSTRADISI MENURUT HUKUM INTERNASIONAL}

Kemajuan-kemajuan dalam bidang ilmu pengetahuan dan teknologi serta berkembangnya pemikiran-pemikiran baru dalam bidang politik, ketatanegaraan, dan kemanusiaan, turut pula memberikan warna tersendiri pada masalah ekstradisi ini. Pemikiran-pemikiran baru itu mendorong semakin diakui dan dikukuhkannya kedudukan individu sebagai subyek hukum dengan segala hak dan kewajibannya.

Beberapa abad yang silam, pada waktu teknologi belum ada dan belum maju, seorang yang melarikan diri dari wilayah negara tempat kejahatan dilakukan tidak dapat bergerak begitu jauh. Paling jauh hanya kedalam wilayah negara tetangga terdekat. Dengan semakin majunya perkembangan teknologi, disamping dapat meningkatkan kesejahteraan hidup umat manusia, dilain pihak dapat menimbulkan berbagai masalah antara lain timbulnya jenis-jenis kejahatan baru yang sangat mengganggu dan mengancam kesejahteraan hidup umat manusia.

Setelah kehidupan bernegara sudah mulai tampak lebih maju, hubungan dan pergaulan internasionalpun mulai mencari dan menemukan bentuknya yang baru. Negara-negara dalam membuat perjanjian-perjanjian, sudah mulai mengadakan pengkhususan mengenai bidangbidang tertentu dan kerjasama dalam berbagai bidang yang kesemuanya ini semakin meningkatkan hubungan antara negara. Demikian juga pada bidang ekstradisi yang sudah lama dikenal dalam praktek, turut pula mencari bentuknya yaitu berbentuk perjanjian ekstradisi yang berdiri sendiri. Jadi tidak lagi menjadi bagian dari masalah-masalah lain yang lebih luas ruang lingkupnya. Negara-negara didalam membuat dan merumuskan perjanjian-perjanjian ekstradiri disamping memperhatikan aspek-aspek untuk memberantas kejahatan juga harus memperhatikan aspek-aspek kemanusiaan dimana individu-individu pelaku kejahatan berada, dengan kata lain, bahwa perjanjian-perjanjian ekstradisi tersebut harus memperhatikan hak-hak asasi dari pelaku tersebut.

Berdarkan asas umum dalam hukujm internasional, setiap negara memiliki kekuasaan tinggai atau kedaulatan atas orang dan benda yang ada dalam wilayahnya sendiri. Olehkarena itu, suatu negara tidak boleh melakukan suatu tindakan yang bersifat kedaulatan didalam wilayah negara lain, kecuali dengan persetujuan negara itu sendiri. Sebab tindakan yang demikian itu dipandang sebagai intervensi atau campur tangan atas masalah-masalah dalam negeri negara lain, yang dilarang menurut hukum internasional. Dalam hubungannya dengan pelaku kejahatan yang melarikan diri atau berada dalm wilayah negara lain, maka negara yang memiliki yurisdiksi atas pelaku kejahatan itu, tidak boleh melakukan penangkapan dan penahanannya secara langsung di dalam wilayah negara tempat si pelaku kejahatan itu berada. Seolah-olah pelaku kejahatan yang demikian itu memperoleh kekebalan dari tuntutan hukum. Tetapi jika hal semacam itu dibiarkan, maka akan dapat mendorong setiap pelaku kejatan, lebih- 
lebih jika dia secara ekonomis tergolong mampu untuk melarikan diri kedalam wilayah negara lain. Hal ini memang semakin sering terjadi. Bahkan usaha untuk melarikan diri kedalam wilayah negara lain tidak hanya dilakukan oleh orang-orang yang bermaksud untuk menghindari ancaman hukuman, tetapi juga oleh orang-orang yang telah dijatuhi hukuman yang telah mempunyai kekuatan hukum mengikat.

Dari uraian diatas, sudah mulai tampak tentang apa yang dinamakan dengan ekstradisi. Dalam berbagai literatur internasioanl kita temukan beberapa istilah tentang ekstradisi. Sebab ekstradisi ini termasuk juga hubungan antara dua negara atau lebih dalam hal penyerahan penjahat ke negara asalnya. Untuk lebih jelasnya lagi mengenai ekstradisi ini maka akan diuraikan pada pembahasan di bawah ini.

\section{a. Pengertian dan Tujuan Ekstradisi.}

Secara umum ekstradisi dapat diartikan pada suatu penyerahan atas pelaku tindakan kejahatan yang telah melarikan diri ke dalam yurisdiksi negara lain. Jadi, inti dari ekstradisi ini adalah penyerahan seseorang kepada negara lain yang berhak memidananya karena telah melakukan suatu kejahatan. Pengertian dari ekstradisi ini terdapat dalam berbagai rumusan tetapi semuanya ini mengandung maksud yang tidak berbeda, dimana salah satunya adalah definisi yang dikemukakan oleh I Wayan Partiana, SH., M.H yang memberikan pengertian sebagai berikut :

"Ekstradisi adalah penyerahan yang dilakukan secara formal baik berdasarkan perjanjianperjanjian ekstradisi yang diadakan sebelumnya atau berdasarkan prinsip timbal balik, atas seseorang yang telah dituduh melakukan tindak pidana kejahatan (tersangka,tertuduh, terdakwa) atau atas seorang yang telah dijatuhi hukuman atas kejahatan yang dilakukannya (terhukum, terpidana) oleh negara tempatnya melarikan diri atau bersembunyi kepada negara yang memiliki yurisdiksi untuk mengadili atau menghukumnya, atas permintaan dari negara tersebut dengan tujuan untuk mengadili atau melaksanakan hukumannya."

Dalam perkembangan lebih lanjut sampai sekarang ini, ekstradisi dipakai untuk memberikan jaminan agar batas-batas internasional yang saat ini tidak lagi merupakan halangan bagi para penjahat atau pelaku tindak pidana, tidak merupakan penghalang bagi terlaksananya peradilan,walaupun sifat teritorialnya dari pada hukum pidana amat ketat serta putusan-putusan peradilan yang dilakukan di luar negeri itu sukar. Adapun yang menjadi tujuan dari ekstradisi pada dasarnya adalah untuk menjamin agar pelaku kejahatan tidak dapat menghindar dari penuntutan atau pemidanaan, karena sering suatu Negara dan wilayahnya dipergunakan sebagai tempat berlindung seorang penjahat. Hal ini semata-mata disebabkan oleh beberapa aturan teknis hukum pidana atau karena tidak adanya yurisdiksi atas penjahat tersebut ${ }^{6}$. Oleh sebab itu patut dan tepatlah penjahat tersebut diserahkan kepada Negara yang berhak untuk memeriksa dan mengadili karena mempunyai yurisdiksi atas penjahat tersebut.

Ekstradisi sebagai suatu lembaga juga berfungsi dan bertujuan melindungi hak-hak asasi manusia. Contohnya, seseorang warga negara Indonesia yang akan dihukum gantung di Malaysia, menurut hukum di Indonesia hal itu tidak sesuai dengan asas kemanusiaan dan tata cara kehidupan bangsa Indonesia, maka Indonesia tentu berusaha meminta agar supaya warga negaranya dihukum di Indonesia saja yaitu dengan jalan orang yang bersangkutan

\footnotetext{
${ }^{6}$ Shamin,AK, Hukum Internasional Publik Jilid 2,Bina Cipta, Bandung, 1992, hal 145
} 
diekstradisikan ke Negara asalnya yaitu Indonesia. Jadi jelas disini ekstradisi memegang peranan penting dalam usaha memberantas kejahatan demi tercipta dan terwujudnya keamanan duni dari masyarakat internasional dan terlindungnya hak-hak asasi manusia.

\section{b. Asas-Asas Ekstradisi yang Dikenal Dalam Hukum Internasional.}

Asas-asas ekstradisi menurut hukum internasional ini berlaku umum bagi perjanjianperjanjian ekstradisi baik bilateral maupun multilateral. Maksudnya adalah didalam pelaksanaan perjanjian ekstradisi ini selalu memuat asas-asas yang sama sebagaimana dikenal dalam hokum Internasional. Asas-asas tersebut adalah :

1. Asas kejahatan ganda (double criminality), yaitu kejahatan yang dijadikan sebagai dasar untuk meminta penyerahan adalah merupakan kejahatan atau peristiwa pidana menurut sistem hukum kedua belah pihak. Penyerahan dapat dilakukan apabila kejahatan tersebut diakui sebagai suatu tindak pidana baik dari negara peminta ataupun di negara yang diminta penyerahannya. Apabila ternyata perbuatan itu merupakan kejahatan menurut sistem hukum salah satu pihak saja, maka permintaan ekstradisi dari negara peminta dapat ditolak. Asas ini juga menentukan bahwa sebagai syarat pelaku suatu tindak pidana dapat diekstradisi atau diminta penyerahannya, ia harus melanggar hukum pidana menurut hukum Negara yang meminta maupun yang diminta.

2. Asas Kekhususan (Speciality), asas ini menentukan bahwa seseorang yang dapat diekstradisi itu tidak boleh diadili dan dihukum melainkan atas kejahatan yang semata-mata dimintakan ekstradisinya. Permintaan ekstradisi tersebut haruslah secara tegas dan terinci menyebutkan jenis atau macam kejahatan yang dijadikan sebagai dasar alasan untuk meminta penyerahan. Hal ini dimaksudkan agar terjaminnya suatu kepastian hukum baik bagi negara peminta maupun bagi negara yang diminta penyerahannya serta bagi orang yang diminta itu sendiri. Sebab salah satu tujuan dari ekstradisi adalah untuk menjamin kepastian hukum bagi atau untuk semua pihak.

3. Asas Tidak Menyerahkan Pelaku Kejahatan Politik (Non Exstradition of Political Criminal). Permintaan penyerahan atau penyerahan atas diri seseorang pelaku kejahatan tidak diperbolehkan jika kejahatan yang dijadikan sebagai dasar untuk meminta penyerahan maupun untuk menyerahkan orang yang bersangkutan adalah suatu kejahatan politik. Kejahatan politik ini mempunyai tempat pengaturan yang tersendiri didalam perjanjianperjanjian dan perundang-undangan yang mengatur mengenai ekstradisi. Kejahatan politik ini dikecualikan dari jenis-jenis kejahatan yang dapat dijadikan dasar untuk meminta penyerahan. Orang yang diminta juga dapat mengajukan pembelaan diri, bahwa kejahatan yang dilakukannya adalah kejahatan politik.

4. Asas Tidak Menyerahkan Warga Negara (Non Exstradition of National), asas ini pada dasarnya memberikan kekuasaan kepada Negara-negara untuk tidak menyerahkan warga Negaranya sendiri yang dituduh melakukan kejahatan didalam wilayah Negara lain atau diluar wilayah suatu Negara. Oleh karena itu, jika orang yang diminta ternyata adalah warga Negara dari Negara yang diminta, Negara tersebut mempunyai kekuasaan untuk menolak permintaan Negara peminta. Kewarganegaraan seseorang sangat memegang peranan yang sangat penting yaitu menyangkut status dari orang yang bersangkutan. Dalam hubungannya dengan ekstradisi, apabila warga Negara dari Negara yang diminta melakukan kejahatan di wilayah Negara lain, maka Negara yang diminta wajib untuk mempertimbangkan apakah warga negaranya itu diserahkan atau tidak. Misalnya, jika dia diserahkan, akan dikawatirkan 
dia diadili menurut sistem hukum dan peradilan yang sangat lain dan asing bila dibandingkan dengan sistem hukum dan peradilan di negaranya sendiri.

5. Asas "Ne bis in Idem", artinya seseorang tidak boleh diadili dan dihukum lebih dari satu kali untuk satu kejahatan yang sama ${ }^{7}$. Berdasarkan asas ini bahwa apabilanterhadap sesuatu kejahatan tertentu telah dijatuhi putusan pengadilan oleh yang berwenang dari Negara yang diminta dan putusan tersebut telah mempunyai kekuatan hokum tetap maka permintaan ekstradisi ditolak.

6. Asas Kadaluwarsa. Artinya penyerahan tidak akan dilakukan apabila penuntutan atau pelaksanaan hukuman terhadap kejahatan yang dijadikan dasar untuk meminta penyerahan telah kadaluwarsa menurut hukum dari salah satu pihak yang mengadakan perjanjian. Makna dari daluwarsa ini adalah memberikan adanya suatu kepastian hukum bagi semua pihak. Bahwa suatu peristiwa hukum apabila sudah dilupakan orang, seolah-olah tidak pernah terjadi, maka setelah sampai atau melewati jangka waktu tertentu tidak bisa diapa-apakan lagi. Mengenai beberapa lama suatu peristiwa hukum sudah dianggap daluwarsa, hal ini berbeda-beda dalam setiap sistem hukum.

\section{c. Syarat-syarat Ekstradisi}

Persoalan mengenai ekstradisi merupakan persoalan yang sangat penting, sebab hal ini berkaitan dengan kebebasan yang merupakan hak asasi dari seseorang yang perlu mendapat perhatian dan perlindungan hukum. Oleh sebab itu seseorang yang diminta penyerahannya untuk diekstradisikan tidak begitu saja dilakukan, melainkan harus sesuai dengan syarat-syarat yang telah ditentukan.

Sebelum suatu permohonan ekstradisi itu dikabulkan,maka terlebih dahulu wajib dipenuhi syarat-syarat yang berkisar pada masalah pokok, yaitu :8

1. Oknum manakah yang dapat dimintakan ekstradisi itu. Yang dapat dikenakan ekstradisi itu hanya oknum yang telah memenuhi syarat-syarat sebagai berikut :

a. Oknum yang melakukan kejahatan disuatu Negara dan tidak di Negara dimana ia ditemukan.

b. Oknum itu harus dicari oleh badan pengadilan suatu Negara.

2. Keadaan apakah yang perlu dipenuhi sebelum ekstradisi itu dikabulkan. Untuk dapat dikabulkan permintaan ekstradisi itu, sebagai syarat umum ditentukan:

a. Tindak pidana yang dilakukan itu harus merupakan tindak pidana biasa, artinya bukan tindak pidana politik. Karena tindak pidana tersebut tidak dapat diekstradisikan. Yang dapat menentukan apakah suatu tindak pidana itu berbentuk politik diserahkan pada Negara peminta.

b. Tindak pidana yang dilakukan itu termasuk salah satu dari tindak pidana yang disebutkan dalam perjanjian ekstradisi yang bersangkutan.

c. Tindak pidana itu harus diancam oleh undang-undang pidana kedua Negara yaitu yang meminta dan Negara yang diminta.

d. Tindak pidana itu sebelumnya tidak pernah terlebih dahulu diputus pengadilan terhadap tindak pidana yang sama.

${ }^{7}$ Eddy Damian, SH, Beberapa Segi Hukum Internasional dan Hukum Nasional Lembaga Ekstradisi, Pro Justisia, Ikatan Alumni, Bandung,1986, hal 227

${ }^{8}$ M. Karjadi, Polisi Internasional, Politea, Bogor, hal 38 
e. Batas waktu yang ditentukan menurut undang-undang yang berlaku pada Negara peminta maupun Negara yang meminta belum dilampaui.

Demikianlah syarat-syarat yang harus dipenuhi dalam ekstradisi. Dengan adanya syaratsyarat tersebut, maka keadilan yang diharapkan oleh setiap Negara dapat tercapai. Syarat-syarat mengenai ekstradisi ini diatur dalam perundang-undangan dari masing-masing Negara dalam hal pelaksanaan penyerahan pelaku kejahatan atau dalam hak pelaksanaan perjanjian ekstradisi.Misalnya didalam Undang-undang No.1 tahun 1979 tentang Ekstradisi mengatur juga mengenai syarat-syarat yang harus dipenuhi dalam mengajukan permohonan ekstradisi yang diatur dalam Bab IV Pasal 22 sampai Pasal 24.

\section{d. Prosedur Ekstradisi.}

Diatas telah dikemukakan beberapa asas yang tertuang dalam ekstradisi. Agar asas-asas tersebut dapat dilaksanakan, diperlukan adanya suatu aturan pelaksanaan sebagai prosedur yang harus dilalui dalam menuntut hak dan melaksanakan kewajiban bagi keduabelah pihak. Prosedurprosedur tersebut antara lain mengenai cara meminta penyerahan, keputusan tentang penerimaan dan penolakan untuk menyerahkan, tempat dan waktu penyerahan dan penahanan sementara orang yang diminta, penyerahan barang yang ada sangkut pautnya dengan kejahatan.

Dilihat dari sumbernya, masalah-masalah prosedur tersebut berasal dari tiga sumber, yaitu perjanjian ekstradisi itu sendiri, perundang-undangan nasional masing-masing Negara tentang ekstradisi, dan peraturan hukum nasional lainnya, khususnya peraturan hokum acara pidana yang berlaku juga untuk masalah ekatradisi. ${ }^{9}$

Prosedur yang bersumber pada hukum atau perjanjian ekstradisi misalnya permintaan penyerahan dan syarat-syaratnya kepada lembaga, yang mana permintaan penyerahan harus diajukan, penahanan sementara orang yang diminta, penyerahan barang-barangnya serta proses penyerahan itu sendiri. Sedangkan prosedur yang bersumber pada hukum atau perundangundangan nasional misalnya, lembaga atau pejabat yang berwenang menangkap si pelaku kejahatan serta menahannya dan peraturan-peraturan hukum yang berlaku atas penahanan tersebut.

Dalam kaitan dengan penentuan kewenangan untuk mengabulkan permintaan ekstradisi dikenal adanya tiga system yang dipraktekkan oleh Negara-negara, yaitu ${ }^{10}$ : Sistem Pertama, menyatakan bahwa ekstradisi merupakan wewenang badan eksekutif semata. Dasar pemikiran dari system ini adalah persoalan ekstradisi merupakan kerjasama dalam penegakan hukum antar Negara, yaitu dengan jalan menyerahkan pelaku tindak pidana yang melarikan diri untuk diadili oleh pengadilan yang berwenang atas kasusnya, tanpa mencampuri masalah wewenang mengadili untuk menentukan bersalah atau tidaknya orang yang diekstradisikan itu. Sistem Kedua, beranggapan bahwa persoalan ekstradisi merupakan atau berkaitan dengan hak asasi seseorang yang harus dilindungi, sekalipun orang tersebut dalam kedudukan sebagai tersangka atau terpidana karena melakukan tindak pidana. Badan yang berwenang untuk menegakkan hokum dan memberikan perlindungan hak asasi manusia adalah badan peradilan. Oleh karena itu, dalam masalah dikabulkan atau ditolaknya suatu permohonan ekstradisi badan yudikatiflah yang memegang peranan penting. Sistem Ketiga, merupakan gabungan dari system pertama dan system kedua. Perlindungan terhadap seseorang pelaku tindak pidana juga harus diimbangi

\footnotetext{
${ }^{9}$ I Wayan Partiana,SH.,M.H,op.cit,hal.119

${ }^{10} \mathrm{Ibid}$
} 
dengan perlindungan umum yang merupakan wewenang dari suatu Negara. Dengan demikian ekstradisi bukan merupakan persoalan hokum semata-mata, tetapi juga menjadi kebijaksanaan pemerintah. Berdasarkan pertimbangan ini baik badan yudikatif maupun badan eksekutif memiliki wewenang untuk menentukan persoalan mengenai ekstradisi.

Dalam permintaan ekstradisi diperlukan adanya suatu permohonan bagi Negara Negara yang diminta. Yang mana permohonan ekstradisi tersebut disampaikan secara tertulis melalui jalur diplomatik, yang ditujukan pada kementrian luar negeri dari Negara yang bersangkutan.

\section{e. Jenis-jenis Kejahatan Yang Dapat Diekstradisi}

Mengenai jenis-jenis kejahatan yang dapat diekstradisi ini terdapat perbedaan-perbedaan diantara masing-masing Negara dan sesuai dengan kesepakatan yang dibuat oleh suatu Negara, yang didasarkan pada suatu perjanjian internasional ataupun didasarkan pada hukum nasional masing-masing Negara.

Meskipun sulit untuk merumuskan suatu prinsip umum tentang kriteria yang dijadikan dasar, namun suatu hal yang ditekankan benar adalah bahwa si penjahat mestilah dianggap sebagai penjahat oleh hukum, baik pada Negara peminta maupun pada Negara yang diminta. Adapun kejahatan yang dapat dimintakan penyerahan kepada negara yang diminta adalah sebagai beriku:

1. Pembunuhan

2. Penyembelihan manusia

3. Perkosaan

4. Pelecehan seksual

5. Penculikan

6. Penculikan anak

7. Melarikan wanita

8. Penguasaan pada seorang wanita

9. Kawin dua

10. Kejahatan yang menyebabkan orang luka berat

11. Perampokan orang

12. Pembakaran

13. Sumpah palsu

14. Perampokan rumah

15. Pencurian dengan kekerasan

16. Penipuan

17. Pemalsuan tandatangan dan uang

18. Pemalsuan barang

19. Pemalsuan surat

20. Kejahatan

21. Penyuapan

22. Merusak harta Negara

23. Kejahatan atau maksud jahat yang berkaitan dengan jalan raya.

Didalam pernyataan jenis-jenis kejahatan yang dapat diekstradisikan tersebut diatas, tidak menyebutkan mengenai kejahatan politik. Hal ini berarti bahwa suatu kejahatan politik tidak dapat dimintakan suaut ekstradisi atas pelaku kejahatan tersebut. Sebab apa yang dimaksudkan dengan kajahatan politik pada awal mula perkembangannya hanyalah kejahatan yang menentang 
pemerintah yang sah atau yang sedang berkuasa. Si pelakunya memang mempunyai keyakinan politik yang berbeda dengan pemerintah yang sedang berkuasa. Prinsip tidak menyerahkan pelaku kejahatan politik ini didasarkan atas penghormatan terhadap hak-hak asasi manusia untuk menganut suatu keyakinan politik, walaupun bebeda dengan politik penguasa yang sah. Pertimbangan lain untuk tidak menyeikrahkan pelaku kejahatan politik adalah walaupun si pelaku kejahtan politik itu pada waktu melakukan kejahatannya atau tepatnya pada waktu melakukan perlawanan terhadap penguasa yang sah secara yuridis formal adalah melakukan tindak pidana, akan tetapi ada kemungkinan pada suatu saat pengusa yang ditentangnya itu tidak berkuasa lagi bahkan ada kemungkinan penguasa yang ditentangnya itu jatuh karena digulingkan oleh pihak lawannya. Oleh sebab itulah berdasarkan pertimbangan-pertimbangan tersebut kejahatan politik tidak dapat diminta penyerahaannya atau kejahatan politik tidak dapat dilakukan ekstradisi.

\section{f. Ancaman Hukuman Dalam Ekrtadisi}

Ancaman hukuman baik Negara peminta maupun Negara yang diminta penyerahannya mungkin saja bisa berbeda-beda.Hal ini berdasarkan ketentuan pidana dari masing-masing Negara. Berat ringannya suatu perbuatan atau tindak pidana itu tergantung pada rasa keadilan dan erat pula dengan ancaman hukuman. Perbedaan ancaman hukuman antara Negara peminta dengan Negara yang diminta penyerahaannya dapat saja terjadi. Hal ini dapat dipahami, sebab setiap Negara mempunyai hak atau berhak dalam menentukan tentang berat atau besarnya ancaman hukuman terhadap suatu perbuatan atau terhadap suatu tindakan kejahatan.

Disamping itu, perbedaan ancaman hukuman mempunyai arti yang sangat penting terhadap semua perjanjian ekstradisi. Yang mana apabila kejahatan yang dijadikan sebagai dasar atau sebagai alasan untuk meminta penyerahaan atas si pelaku kejahatan di ancam dengan hukum mati oleh Negara peminta. Sedangkan oleh Negara yang diminta diancam dengan hukuman yang lebih ringan, setidak-tidaknya bukan diancam dengan hukuman mati.

Perbedaan ancaman hukuman ini amat penting khususnya antara hukuman mati dengan bukan hukuman mati. Sebab persoalan yang menyangkut atau bertalian dengan masalah hidup atau matinya seseorang erat hubungannya dengan ancaman hukuman tersebut. Apakah di ancam dengan hukuman mati atau tidak. Perbedaan ancaman hukuman ini mempunyai kepincangankepincangan dan sulit untuk menerapkan hukuman yang akan dipakai atau digunankan. Misalnya, Indonesia dan Malaysia sama-sama masih mempertahankan hukuman mati. Tetapi di Malaysia kejahatan yang dapat diancam dengan hukuman mati adalah kejahatan korupsi. Sedangkan pembunuhan berencana di Malaysia tidak diancam dengan dengan hukuman mati, demikian pula sebaliknya di Indonesia kejahatan mengenai korupsi tidak di ancam dengan hukuman mati. Jadi jelaslah disini terdapat perbedaan jenis kejahatan yang diancam dengan hukuman mati atau tidak.

Untuk mengatasi hal ini, ditempulah suatu jalan dengan mencantumkan suatu ketentuan didalam perjanjian ekstradisi yang bersifat kompromi. Yaitu,Penyerahaan tetap dapat dilakukan melalui prosedur ekstradisi, tetapi dengan penyerahaan jika menurut hukum Negara yang diminta,kejahatan yang dijadikan sebagai dasar untuk meminta penyerahaan tidak diancam hukuman mati oleh hukum Negara diminta atau hukuman mati biasanya tidak pernah dilaksanakan, tetapi menurut hukuman Negara diminta kejahatan itu diancam dengan hukuman mati atas diri sipelaku kejahatan tersebut. 
Berdasarkan alasan diatas,maka disimpulkan bahwa usaha-usaha untuk menghindari hukuman mati dimaksudkan untuk lebih menekankan pada segi-segi hak asasi manusia, yang salah satu diantaranya adalah hak untuk hidup.

\section{EKSTRADISI MENURUT HUKUM NASIONAL INDONESIA}

Seperti halnya dengan Negara-negara lain, Negara Indonesia juga memiliki perundangundangan yang mengatur mengenai ekstradisi ini. Hal ini dimaksudkan agar adanya suatu kepastian hukum dalam permintaan maupun penyerahan pelaku kejahatan yang telah melarikan diri baik ke dalam Negara Indonesia sendiri ataupun ke Negara lain. Dalam perundang-undangan mengenai ekstradisi ini diatur dalam Undang-undang No.1 Tahun 1979.

\section{a. Pengertian Ekstradisi Menurut UU Nomor 1 Tahun 1979}

Sebelum lahirnya undang-undang ini, pengaturan mengenai ekstradisi terdapat dalam staatblad No.188 Tahun 1983. Staatblad ini tidak sesuai lagi dengan alam Indonesia yang mencita-citakan terbentuknya hukum nasional. Oleh karena itu sudah waktunya diganti dengan undang-undang ekstradisi nasional. Undang-undang No.1 Tahun 1979 dimaksudkan untuk memberikan dasar hukum bagi pembuatan perjanjian denagan Negara-negara asing. Adapun yang dimaksud dengan ekstradisi dalam Pasal 1 Undang-undang No.1 Tahun 1979 ini adalah :

"Penyerahan oleh suatu Negara kepada Negara yang meminta penyerahan seseorang yang disangka atau dipidana karena melakukan suatu kejahatan di luar wilayah Negara menyerahkan dan di dalam yurisdiksi wilayah Negara yang meminta penyerahan tersebut karena wewenang untuk mengadili dan memidananya".

Dengan adanya Undang-undang ini, memperlihatkan bahwa Indonesia juga turut serta berperan dalam usaha pemberantasan kejahatan. Pernyataan ini dimaksudkan agar terciptanya perdamaian yang kita cita-citakan baik di kawasan Asia maupun dunia internasional. Dengan perjanjian ekstradisi lebih memudahkan suatu Negara untuk meminta penyerahan atas pelaku kejahatan yang melarikan diri ke Negara lain. Sebab, sebagaimana yang kita ketahuitanpa adanya suatu perjanjian ekstradisi itu tidak dapat dilaksanakan atau dilakukan.

\section{b. Asas-asas yang Terkandung Dalam Undang Undang Nomor 1 Tahun 1979 Tentang Ekstradisi}

Didalam penjelasan umum undang-undang mengenai ekstradisi ini diatur asas-asas umum dalam ekstradisi, antara lain:

1. Asas kejahatan rangkap, yaitu bahwa perbuatan yang dilakukan baik oleh Negara peminta maupun oleh Negara yang diminta dianggap sebagai kejahatan.

2. Asas jika suatu kejahatan tertentu oleh Negara yang diminta dianggap sebagai kejahatan politik maka permintaan ekstradisi ditolak.

3. Asas bahwa Negara yang diminta mempunyai hak untuk tidak menyerahkan warganegaranya sendiri.

4. Asas bahwa suatu kejahatan yang telah dilakukan seluruhnya atau sebagian di wilayah yang termasuk atau dianggap termasuk dalam yurisdiksi Negara yang diminta, maka Negara ini dapat menolak permintaan ekstradisi. 
5. Asas bahwa suatu permintaan ekstradisi dapat ditolak jika pejabat yang berwenang dari Negara yang diminta sedang mengadakan pemeriksaan terhadap orang yang bersangkutan mengenai kejahatan yang dimintakan peneyerahannya.

6. Asas bahwa apabila terhadap suatu kejahatan tertentu, suatu keputusan yang telah mempunyai kekuatan pasti telah dijatuhkan oleh pengadilan yang berwenang dari Negara yang diminta, permintaan ekstradisi ditolak.

7. Asas bahwa seseorang tidak diserahkan karena hak untuk menuntut atau hak untuk melaksanakan putusan pidana telah kadaluwarsa.

8. Asas bahwa seseorang yang diserahkan tidak akan dituntut, dipidana atau ditahan untuk kejahatan apapun yang dilakukan sebelum yang bersangkutan diekstradisikan selain daripada untuk kejahatan mana ia diserahkan, kecuali bila Negara yang diminta untuk menyerahkan orang itu menyetujuinya.

\section{PROSES PERJANJIAN EKSTRADISI INDONESIA-MALAYSIA DALAM USAHA MEMBERANTAS KEJAHATAN}

Pemerintah Indonesia dan pemerintah Malaysia sepakat untuk meningkatkan terus keamanan diantara kedua Negara. Kerjasama yang selama ini telah berjalan memerlukan pula partisipasi dari masyarakat. Untuk lebih mempererat hubungan diantara kedua Negara, maka perlu sering diadakan pertemuan-pertemuan dan kegiatan-kegiatan dalam rangka pemberantasan kejahatan ${ }^{11}$.

Latar belakang geografis dan persamaan kebudayaan telah mendorong pemerintah Indonesia dan pemerintah Malaysia mengadakan perjanjian mengenai penyerahan penjahat atau yang lebih dikenal dengan ekstradisi. Apalagi dengan kemajuan teknologi dan transportasi dewasa ini memudahkan para pelaku tindak kejahatan untuk melepaskan diri dari tuntutan hokum. Untuk itu maka dirasakan perlu dibentuknya suatu perjanjian megenai penyerahan penjahat yang telah melarikan diri. Dibentuknya perjanjian ini bertujuan untuk menciptakan keamanan dimasingmasing Negara serta ikut sertanya dalam usaha pemberantasan kejahatan.

Oleh karena itu, untuk mempermudah penyerahan pelaku kejahatan ke Negara asalnya maka dibentuklah suatu perjanjian yang khusus mengatur mengenai hal ini, yaitu perjanjian yang dikenal dengan perjanjian ekstradisi. Maka pada tanggal 18 dan 19 Maret 1974 bertempat di ruang sidang Departemen Kehakiman Jakarta telah diadakan suatu perundingan perjanjian megenai ekstradisi yang tertuang dalam Undang-undang No.9 Tahun 1974 Tentang Pengesahan Perjanjian Ekstradisi Antara Pemerintah Indonesia Dengan Pemerintah Malaysia. Adapun hal-hal pokok yang disampaikan dalam perundingan tersebut adalah sebagai berikut: ${ }^{12}$

a. Perjanjian Ekstradisi yang hendak kita capai tidak hanya merupakan usaha-usaha yang sama dalam memberantas kejahatan umum, tetapi juga mempunyai tujuan mempererat persahabatan diantara dua Negara, yaitu Indonesia dan Malaysia;

b. Diharapkan, bahwa perjanjian ini akan merupakan langkah pertama yang penting yang akan diikuti oleh perjanjian disemua bidang kegiatan pemerintah, dan dengan demikian akan memperkuat ikatan diantara dua Negara;

c. Perjanjian Ekstradisi tidak hanya merupakan suatu perjanjian dalam mana suatu pihak mencoba semua jalan kemungkinan untuk mencapai hasil maksimum, tetapi lebih merupakan

${ }^{11}$ Suara Karya, Hubungan Indonesia-Malaysia Jangan Diabaikan, Terbit 26 Januari 1990

12 Sejarah Pembentukan Undang Undang Tentang Pengesahan Perjanjian antara Pemerintah Indonesia dengan Pemerintah Malaysia mengenai Ekstradisi, disusun oleh Dirjen Hukum dan Perundang-undangan Departemen Kehakiman,1974, hal 11 
suatu usaha kerjasama diantara dua Negara yang bersahabat dalam memberantas kejahatan. Karena itu didalam pertemuan ini kita tidak akan menekankan pada kontradiksi yang ada, tetapi lebih menekankan pada dasar umum bahwa tidak ada seorang penjahatpun yang akan lolos dari penuntutan.

Jadi jelaslah bahwa antara pemerintah Indonesia dan pemerintah Malaysia sama-sama membutuhkan adanya suatu perjanjian yang mengatur mengenai penyerahan penjahat. Perjanjian ini mulai berlaku pada tanggal 11 Agustus 1975. Perjanjian ini telah mendorong dan telah menjadi pedoman bagi bangsa Indonesia dalam membuat perundang-undangan nasional mengenai ekstradiisi dan menjadi pedoman dalam membuat perundang-undangan tentang Ekstradisi dengan Negara-negara lain sperti dengan Singapura, Filipina dan Negara-negara di AsiaTenggara.

\section{a. Kejahatan Yang Dapat Dimintakan Penyerahan}

Sebelum ekstradisi itu dilaksanakan, kedua belah Negara baik Indonesia maupun Malaysia harus mengetahui kejahatan-kejahatan apa yang dapat dimintakan penyerahan. Kejahatan-kejahatan yang dimintakan penyerahan tersebut telah disepakati oleh kedua Negara. Pasal 2 UU No.9 Tahun 1974 Tentang Ekstradisi antara pemerintah Indonesia dengan pemerintah Malaysia memuat 26 butir kejahatan dan satubutir lagi menyebutkan lain-lain kejahatan yang ditambahkan sewaktu-waktu dengan persetujuan kedua belah pihak. Adapun jenis-jenis kejahatan yang dimaksudkan dalam Pasal 2 tersebut adalah sebagai berikut:

1. Pembunuhan dengan rencana dan maker untuk melakukan pembunuhan.

2. Pembunuhan

3. Perkosaan

4. Penculikan dan penculikan anak

5. Penganiayaan

6. Perampasan kemerdekaan seseorang secara melawan hokum

7. Perdagangan budak

8. Kejahtan-kejahatan yang dilakukan terhadap wanita dan gadis

9. Pencurian dengan pengrusakan, pencurian dan tindak pidana yang bersangkutan dengan pencurian

10. Penculikan dengan kekerasan

11. Pemalsuan dan tindak pidana yang bersangkutan dengan pemalsuan

12. Penggelapan

13. Penipuan

14. Perbuatan curang

15. Penyuapan dan korupsi

16. Pemerasan

17. Kejahatan yang berhubungan dengan uang kertas, mata uang dan materai

18. Penyelundupan

19. Menimbulkan kebakaran

20. Kesalahan-kesalahan yang boleh dihukum dibawah undang-undang berhubungan dengan daerah berbahaya

21. Pembajakan laut

22. Menenggelamkan atau merusak kapal di laut, atau percobaan atau pemufakatan jahat melakukan kejahatan tersebut. 
23. Penyerangan diatas kapal laut, atau percobaan atau permufakatan jahat melakukan kejahatan tersebut

24. Pemberontakan atau permufakatan jahat untuk memberontak oleh dua orang atau lebih diatas kapal dilaut terhadap kekuasaan nakhoda.

25. Sumpah palsu, member, membuat dan menggunakan bukti palsu

26. Penghancuran atau pengrusakan barang

27. Lain-lain kejahatan yang ditambahkan sewaktu-waktu pada lampiran ini dengan persetujuan kedua belah pihak.

Bila kita perhatikan jenis-jenis kejahatan tersebut diatas, maka dapat disimpulkan bahwa kejahatan yang dimintakan penyerahan itu adalah kejahatan yang tergolong kejahatan berat seperti pembunuhan dan lain-lain.

\section{b. Syarat-syarat dan Proses Penyerahan}

Sebelum penyerahan atas pelaku kejahatan yang dilakukan, Negara peminta harus memenuhi terlebih dahulu syarat-syarat yang diajukan oleh Negara yang diminta penyerahan mengenai penyerahan pelaku kejahatan tersebut. Pasal 15 UU No.9 Tahun 1974 menyebutkan syarat-syarat atau dokumen-dokumen yang diperlukan dalam permintaan ekstradisi adalah sebagai berikut:

1. Permintaan penyerahan wajib dinyatakan secara tertulis dan dikirim di Indonesia kepada Menteri Kehakiman di Malaysia kepada Menteri yang bertanggung jawab atas pelaksanaan peradilan melalui saluran diplomatic.

2. Permintaan penyerahan wajib disertai:

a) Lembaran asli atau salinan yang disahkan dari penghukuman dan pidana yang dapat segera dilaksanakan atau surat perintah penahanan lainnya yang mempunyai akibat yang sama dan dikeluarkan sesuai dengan tata cara yang ditetapkan dalam hukum pihak peminta.

b) Keterangan dari kejahatan yang dimintakan penyerahannya, waktu dan tempat kejahatan dilakukan, uraian yuridis dan penunjukan pada ketentuan-ketentuan hukum yang bersangkutan diuraikan secermat mungkin.

c) Salinan dari peraturan-peraturan yang bersangkutan

3. Dokumen-dokumen yang digunakan dalam proses penyerahan akan dibuat dalam bahasa Inggris

Setelah memperhatikan isi dari Pasal 15 tersebut,sebelum penyerahan atas pelaku tindak pidana dilakukan harus memperhatikan terlebih dahulu ketentuan-ketentuan sebagaimana termuat dalam Pasal 2 yang intinya berisikan kejahatan-kejahatan yang dapat dimintakan penyerahan. Sebab hanya kejahatan-kejahatan yang termuat dalam Pasal 2 yang dapat dimintakan penyerahannya.abila dokumen-dokumen dan persyaratan telah dipenuhi oleh Negara peminta dan telah mendapat persetujuan, maka Negara peminta dapat meminta kepada Negara yang diminta tersebut untuk melakukan penahanan sementara terhadap pelaku kejahatan itu. Hal ini dimaksudkan agar orang tersebut tidak melrikan diri lebih jauh lagi. Permintaan penahanan sementara ini disampaikan di Indonesia kepada Interpol dan di Malaysia kepada Ketua Polisi Negara atau melalui saluran diplomatic. Pernyataan ini sesuai dengan Pasal 9 ayat (3) mengenai penahanan sementara. Selanjutnya Pasal 9 ayat (5) menyebutkan bahwa penahanan sementara dapat diakhiri jika dalam waktu 20 hari setelah penahanan pihak yang diminta tidak menerima permintaan penyerahan serta belum lengkapnya dokumen-dokumen yang disebut dalam Pasal 
15. Ini berarti bahwa seseorang yang ditahan tersebut dibatasi dalam waktu tertentu, gunanya adalah agar orang tersebut tidak ditahan berlarut-larut dan ada kepastian hukumnya.

Setelah dokumen atau syarat-syarat telah terpenuhi dan telah mendapat persetujuan serta telah dilakukan penahanan sementara atas pelaku kejahatan tersebut, maka selanjutnya penyerahan tersebut dapat dilakukan sebagai mana termuat dalam Pasal 10 undang-undang tersebut. Selanjutnya Pasal 13 menyebutkan bahwa tata cara mengenai penyerahan dan penahanan akan tunduk pada hukum pihak yang diminta.

Berdasarkan uraian diatas jelas bahwa tercipta atau terlaksananya dengan baik perjanjian ekstradisi antara kedua Negara sangat tergantung pada bagaimana masing-masing Negara dapat melaksanakan perjanjian penyerahan penjahat tersebut sesuai dengan perjanjian Ekstradisi. Hal inilah yang menjadi tujuan dari masing-masing Negara yaitu terciptanya keamanan dan kerjasama diantara kedua Negara serta ikut sertanya dalam usaha memberantas kejahatan dan mewujudkan perdamaian dunia.

\section{c. Saat Mulai dan Berakhirnya Perjanjian}

Perjanjian ekstradisi ini mulai berlaku pada tanggal penukaran piagam ratifikasi yaitu pada tanggal 11 Agustus 1975 yang diadakan di Kuala Lumpur, yang termuat dalam dalam Pasal 17. Pasal 18 undang-undang tersebut mengatur mengenai berakhirnya perjanjian yang berisikan"perjanjian ini dapat diakhiri setiap waktu oleh salah satu pihak dengan memberitahukan maksud untuk melakukan itu 6 (enam)bulan sebelumnya.

Demikianlah proses pelaksanaan perjanjian ekstradisi antara pemerintah Indonesia dengan Pemerintah Malaysia, yang kesemuanya ini tidak terlepas dan dimuat didalam UndangUndang No.9 Tahun 1974 Tentang Pengesahan Pejanjian Ekstradisi Antara pemerintah Indonesia Dengan Pemerintah Malaysia.

\section{d. Contoh kasus Ekstradisi Indonesia-Malaysia}

1. Fadli Sadama seorang teroris berwarga Negara Indonesia, bertindak sebagai penyetor dana untuk pelatihan Militer di Aceh yang juga tersangka perampokan CIMB Niaga telah ditangkap di Malaysia pada tanggal 13 Oktober 2010 dan dipulangkan atas permintaan ekstradisi Indonesia pada tanggal 04 Desember 2010.

\section{PENUTUP}

\section{Kesimpulan}

Berdasarkan uraian diatas, maka dapat disimpulkan sebagai berikut :

a. Pelaksanaan perjanjian ekstradisi antara pemerintah Indonesia dan pemerintah Malaysia ditentukan dan ditetapkan dalam Undang-undang No.9 Tahun 1974 yang didalamnya memuat mengenai jenis-jenis kejahatan yang dapat dimintakan penyerahan, syarat-syarat penyerahan, prosedur serta penahanan sementara dan masih banyak lainnya lagi yang diatur dalam undang-undang tersebut, yang kesemuanya dijadikan dasar dan pedoman dalam pelaksanaan ekstradisi diantara kedua negara. 
b. Setelah syarat-syarat permohonan ekstradisi telah terpenuhi dan telah mendapat persetujuan untuk melaksanakan ekstradisi barulah kepolisian dari masing-masing negara mendapatkan tugas untuk melakukan penangkapan dan penahanan atas pelaku tindak kejahatan tersebut. Disinilah peran kepolisian dalam usaha untuk menangkap daan menahan pelaku kejahatan yang telah melarikan diri.

c. Perjanjian ekstradisi antara pemerintah Inddonesia dengan pemerintah Malaysia ini sangat bermanfaat untuk terwujudnya perdamaian dan keamanan di wilayah masingmasing negara, serta ikut sertanya dalam usaha memberantas kejahatan yang dicitacitakan setiap bangsa. Perjanjian ekstradisi dengan Malaysia ini telah mendorong bangsa Indonesia untuk menyusun dan membuat perundang-undangan nasional yang khusus mengatur tentang ekstradisi.

\section{Saran}

Untuk lebih terlaksananya perjanjian ekstradisi antara pemerintah Indonesia dan pemerintah Malaysia serta pelaksanaannya di Indonseisa, maka yang dapat penulis sarankan adalah sebagai berikut :

a. Sebagai masyarakat diperlukan peran sertanya dalam memberikan informasi apabila mengetahui ada pelarian penjahat ke dalam wilayahnya. Masyarakat juga mempunyai andil yang sangat penting dalam memberikan informasi kepada pihak kepolisian

b. Indonesia perlu mengadakan perjanjian ekatradisi dengan negara-negara lain, tidak hanya dikawasan Asia tenggara saja. Hal ini akan mempermudah proses penyerahan pelaku kejahatan yang telah melarikan diri.

c. Perlu diadakannya penyusunan dan penambahan ketentuan-ketentuan didalam undang-undang nomor 9 tahun 1974, yang disesuaikan dengan peerkembangan zaman sekarang ini. Sebab sebagaimana yang kita ketahui bahwa perjanjian ekstradisi antara pemerintah Indonesia dan pemerintah Malaysia ini umurnya sudah cukup lama.

d. Agar terwujudnya keamanan dan ketertiban didalam wilayah negara Indonesia, diperlukan aparatur negara yang bertanggung jawab, dan melaksanakan tugas serta tanggung jawabnya kepada negara sehingga apabila terjadi pelarian penjahat atau masuknya penjahat kedalam wilayah Indonesia dapat segera dideteksi dan segera dilakukan pengejaran.

e. Diperlukannya kerjasama yang baik antara pemerintah Indonesia dengan pemerintah Malaysia dalam hal pemulangan penjahat ke negara asalnya, hal ini dimaksudkan agar terwujudnya keamanan di kawasan Asia Tenggara serta ikut sertanya dalam usaha pemberantasan kejahatan.

\section{DAFTAR PUSTAKA}

\section{Literatur :}

Abdurrahman, Aneka Masalah Hukum Dalam Perkembangan Di Indonesia, Alumni Bandung, 1979.

B. Sen. A, Diplomat's Hand Book Of International Law and Practice, London, 1979

Eddy Damian, Kapita Selekta Hukum Internasional, Alumni, Bandung, 1991 
Eddy Damian, Beberapa Segi Hukum Internasional dan Hukum Nasional Lembaga Ekstradisi, Bandung, 1986

FX. Adji Samekto, S.H., M.H, Negara Dalam Dimensi Hukum Internasional, penerbit PT.Citra Aditya Bakti, Bandung, 2009

M. Budiarto, Masalah Ekstradisi dan Jaminan Perlindungan Atas Hak-hak Asasi Manusia, Ghalia, Jakarta-Indonesia, 1980

M. Karjadi, Polisi Internasional, Politea, Bogor, 1987

Sudarto, SH, Hukum Pidana I, Yayasan Sudarto, Semarang, 1990

Sardjono, Kerjasama Internasional Di Bidang Kepolisian, penerbit National Central Bureau Indonesia-Interpol, Jakarta, 1996

Shamin AK, Hukum Internasional Publik Jilid 2, Bina Cipta, Bandung, 1992

Sejarah Pembentukan Undang-Undang Tentang Pengesahan Perjanjian antara IndonesiaMalaysia mengenai Ekstradisi, disusun oleh Dirjen Hukum dan Perundang-Undangan Departemen Kehakiman, 1979

Suara Karya, Hubungan Indonesia-Malaysia Jangan Diabaikan, terbit 26 Januari 1990 